\title{
CULICOIDES LATREILLE (DIPTERA, CERATOPOGONIDAE) \\ IN BRAZILIAN AMAZON. V. EFFICIENCY OF TRAPS AND \\ BAITS AND VERTICAL STRATIFICATION IN THE FOREST RESERVE ADOLPHO DUCKE
}

\author{
Rosana S. Veras ${ }^{1}$ \\ Eloy G. Castellón ${ }^{2}$
}

\begin{abstract}
Monthly catches were carried out during five days/month in the Adolpho Ducke Forest Reserve (Manaus, Amazonas), from February 1990 to January 1991 in order to assess the sandfly fauna of that region, evaluate the atractivity of these insects with regard to different kinds of traps and baits and to know vertical stratification of these insects. The traps and baits used in catches were: Disney traps with baits: Didelphis sp., Gallus sp. and Mesocricetus sp.; CDC light traps at three vertical levels $(1 \mathrm{~m}, 5 \mathrm{~m}$ and $10 \mathrm{~m})$; Suspended trap $(5 \mathrm{~m})$ and Malaise trap $(1 \mathrm{~m})$ and catches on bases of tree-trunks. The most efficient type was the CDC. Malaise and Suspended did not collect specimens of Culicoides Latreille, 1809. The Disney traps with baits only attracted specimens of $C$. fusipalpis Wirth \& Blanton, 1973. In vertical stratification, the CDC trap placed at $1 \mathrm{~m}$ caught 898 specimens of nine species; at $5 \mathrm{~m} 895$ specimens were collected which belonged to 13 species; and at $10 \mathrm{~m} 224$ specimens of 14 species were collected. Two thousand and forty-six specimens of Culicoides were captured, being about $5,66 \%$ males and $94,34 \%$ females, which belonged to 17 different species; the most frequent were $C$. fusipalpis (43,05\%), followed by C. pseudodiabolicus Fox, 1946 (32,79\%), C. hylas Macfie, 1940 (12,31\%) and C. foxi Ortiz, 1950 (3,71\%). The other 13 species totalized $8,15 \%$.

KEY WORDS. Diptera, Caratopogonidae, Culicoides, traps and baits, vertical stratification, Amazon
\end{abstract}

The insects of the genus Culicoides Latreille, 1809 are known by several names in different countries; in Brazil they are called "maruins", "mosquitos pólvora" and "mosquito do mangue" (FORATTINI et al. 1958). The bite of these insects is painful and gives a burning sensation. The bite may cause serious damages to the skin of sensitive persons, sometimes with a strong reaction (SHERLOCK \& GUITTON 1964). Only the females are bloodsuckers.

Several kinds of traps and baits are in use by dipterologists to collect material for taxonomic and ecological studies, and to assess the geographical distribution, seasonal variation, relative abundance and vertical stratification of several species.

1) Instituto Nacional de Pesquisas da Amazônia, Fundação Universidade do Amazonas. Alameda Cosme Ferreira 1756, 69083-970 Manaus, Amazonas, Brazil. CAPES scholarship student.

2) Instituto Nacional de Pesquisas da Amazônia, Coordenação de Pesquisas em Entomologia. Alameda Cosme Ferreira 1756, 69083-970 Manaus, Amazonas, Brazil. 
The CDC trap has been used by several authors for surveys of the dipterous fauna in many parts of the world, obtaining good results in the collections of populations of anthropophilic and non-anthropophilic species.

The Disney trap (DISNEY 1965) whose main purpose is to collect insects who are attracted towards different kinds of animal bait, has been used in the study of food preferences with different animal baits and has a proven efficiency in the capture of bloodsucking Diptera.

The suspended trap (RAFAEL \& GORAYEB 1982) has been used to collect Tabanids in different altitudinal layers in the forest. Gorayeb (comunição pessoal) used this kind of trap at different heights from the soil $(1.6 \mathrm{~m}, 7 \mathrm{~m}$ and $23 \mathrm{~m})$, obtaining specimens of 33 species of tabanideous with a significant variation between different heights in connection with the number of species collected.

The Malaise is a kind of interception trap, used to collect insects who fly at low highs. However, it can be suspended at different heights among the trees.

The insects who shelter in the cracks, roots and tree cavities can be captured through the collections on the bases of the trees with a modified CDC.

The objective of this work was to assess the efficiency of different traps and baits in the capture of Culicoides and to evaluate the vertical stratification of this genus in the Adolpho Ducke Forest Reserve, Amazon state, Brazil.

\section{MATERIAL AND METHODS}

This work was made in an area of the primary forest at the Adolpho Ducke Forest Reserve, of the National Research Institute of the Amazon Region, Manaus, situated at $26 \mathrm{~km}$ of the AM 010 Road; with geographic position $\left(03^{\circ} \mathrm{S}, 59^{\prime} \mathrm{W}\right)$, consisting of an area of $10.072 \mathrm{Ha}$ and with approximated elevation of 80 to 100 meters above the sea level. Data about vegetation, refer to LECHTHALER (1956), AubreViLle (1961), Higuchi (1981).

\section{Types of collections}

The catches were made for 12 months, during five days/month, from February 1990 to January 1991. Five different types of collecting strategies were used to capture Culicoides: Light trap CDC, Disney traps with animal baits, Suspended trap, Malaise trap and collections on the base of the trees.

\section{CDC traps (SUDIA \& CHAMBERLAIN 1962)}

Three CDC type were used; each trap was placed at different heights from the soil: $1 \mathrm{~m}, 5 \mathrm{~m}$ and at $10 \mathrm{~m}$, working from 18:00 pm until 6:00 am next day.

\section{Disney traps (DISNEY 1965)}

These traps were put at a height of $50 \mathrm{~cm}$ from the soil and protected from the rain with plastic, put at $50 \mathrm{~cm}$ above each trap. A slim layer of mineral oil was applied in the higher surface of the trays to facilitate the fixation of the insects. Three Disney traps were used with three different kinds of baits: Didelphis sp. (opposum); Gallus sp. (chicken) and Mesocricetus sp. (hamster). The baits were placed at 18:00 and removed at $6: 00 \mathrm{~h}$. The captured insects were removed with brushes and entomological tweezers and conserved in $70 \%$ alcohol. 


\section{Suspended trap (RAFAEL \& GORAYEB 1982)}

The modification made to elaborated pattern by RAFAEL \& GORAYEB (1982) consisted in to place a black textile connected to interne superior border that attract the insects, who goes to the collector tube.

This trap was settled at $5 \mathrm{~m}$ height from the soil working from 18:00 pm until 6:00 am next day.

\section{Malaise trap (TOWNES 1962)}

This trap was settled with the inferior border at the ground and the four superior borders stretched and fixed, with cords, at the branches of the trees and it worked from 18:00 pm until 6:00 am next day.

\section{Catches on bases of tree-trunks}

They were done using a modified CDC trap, working as an aspirator and a tulle bag coupled to its opposite edge aiming to collect the insects who take shelter in cracks, holes and reentrances of the tree bases. The trapping at a height of $1.2 \mathrm{~m}$, mainly in trees with a diameter superior $2 \mathrm{~m}$. The modifications done to the model worked up by SUDIA \& CHAMBERLAIN (1962) consisted of adding a little PVC tube in the shape of a $10 \mathrm{~cm}$ lenght cone, $12 \mathrm{~cm}$ of diameter at the inferior base and $8 \mathrm{~cm}$ at the superior opening, coupled in the inferior side of the cylinder/trap, as well as the removal of the lid and the source of light to make handling easy.

The collections with the modified CDC were done in the morning from 8:00 to $9: 00 \mathrm{~h}$ and in the afternoon from 14:00 to 15:00 h, totalizing 120 hours of collections. The collected material was separated and submitted to the process of preparation, clearing and assembly on a slide with cover slide, according to the methodology used by CASTELLÓN \& FERREIRA (1991).

The mounting was made on a stereoscopic microscope with the aid of two dissecting needles. The specimens were removed from the phenol and individually put at the center of a slide, in a drop of Canada balsam, dissected and covered by a cover slide of the size $11 \times 11 \mathrm{~mm}$. The slide containing the mounted material was placed in a stove at $38^{\circ} \mathrm{C}$ temperature to dry for about 3 to 4 days. Afterwards the species was identified.

\section{RESULTS}

Two thousand and forty six $(2,046)$ specimens of Culicoides were collected, belonging to 17 species, in a period of 12 months.

The species and the total number of specimens (females and males) collected in the different traps and baits are listed in table I.

The most frequent species were Culicoides fusipalpis Wirth \& Blanton, 1973 (43,05\%), C. pseudodiabolicus Fox, 1946 (32,79\%); followed by C. hylas Macfie, $1940(12,31 \%)$ and C. foxi Ortiz, $1950(3,71 \%)$; the others 13 species totalized $8,15 \%$.

The trap by which the largest number of species was collected, was the CDC light trap with $98,6 \%$ of the total, followed by the collections at bases of tree-trunks with $0,8 \%$ and in the Disney traps with $0,6 \%$. 
Table I. Species and specimes of the genus Culicoides collected in different traps and baits in the Adolpho Ducke forest reserve, during February of 1990 to January of 1991.

\begin{tabular}{|c|c|c|c|c|c|c|c|c|c|c|c|c|c|c|c|c|c|}
\hline \multirow{3}{*}{ Culicoides species } & \multicolumn{6}{|c|}{ CDC Traps } & \multicolumn{6}{|c|}{ Disney baits } & \multirow{2}{*}{\multicolumn{2}{|c|}{$\begin{array}{c}\text { Base of } \\
\text { tree }\end{array}$}} & \multirow{2}{*}{\multicolumn{2}{|c|}{ Total }} & \multirow{3}{*}{$\begin{array}{l}\text { Total } \\
\text { Geral }\end{array}$} \\
\hline & \multicolumn{2}{|c|}{$1 \mathrm{~m}$} & \multicolumn{2}{|c|}{$5 \mathrm{~m}$} & \multicolumn{2}{|c|}{$10 \mathrm{~m}$} & \multicolumn{2}{|c|}{ Didelphis } & \multicolumn{2}{|c|}{ Hamster } & \multicolumn{2}{|c|}{ Gallus } & & & & & \\
\hline & $F$ & M & $\mathrm{F}$ & M & $\mathrm{F}$ & M & $\mathrm{F}$ & M & $\mathrm{F}$ & M & $\mathrm{F}$ & M & $\mathrm{F}$ & M & $F$ & M & \\
\hline Culicoides bricenoi & 0 & 0 & 1 & 0 & 1 & 0 & 0 & 0 & 0 & 0 & 0 & 0 & 0 & 0 & 2 & 0 & 2 \\
\hline C. dasyophrus & 0 & 0 & 3 & 0 & 1 & 1 & 0 & 0 & 0 & 0 & 0 & 0 & 1 & 0 & 5 & 1 & 6 \\
\hline C. eublepharus & 0 & 0 & 1 & 0 & 0 & 0 & 0 & 0 & 0 & 0 & 0 & 0 & 0 & 0 & 1 & 0 & 1 \\
\hline C. foxi & 15 & 0 & 48 & 0 & 13 & 0 & 0 & 0 & 0 & 0 & 0 & 0 & 0 & 0 & 76 & 0 & 76 \\
\hline C. fusipalpis & 380 & 0 & 413 & 5 & 67 & 3 & 9 & 0 & 1 & 0 & 3 & 0 & 0 & 0 & 873 & 8 & 881 \\
\hline C. glabrior & 1 & 0 & 0 & 0 & 0 & 0 & 0 & 0 & 0 & 0 & 0 & 0 & 0 & 0 & 1 & 0 & 1 \\
\hline C. hylas & 77 & 41 & 66 & 13 & 26 & 16 & 0 & 0 & 0 & 0 & 0 & 0 & 5 & 8 & 174 & 78 & 252 \\
\hline C. insignis & 1 & 0 & 0 & 0 & 0 & 0 & 0 & 0 & 0 & 0 & 0 & 0 & 0 & 0 & 1 & 0 & 1 \\
\hline C. lahillei & 11 & 0 & 19 & 6 & 21 & 0 & 0 & 0 & 0 & 0 & 0 & 0 & 1 & 0 & 52 & 6 & 58 \\
\hline C.leopoldoi & 0 & 0 & 2 & 1 & 2 & 0 & 0 & 0 & 0 & 0 & 0 & 0 & 0 & 0 & 4 & 1 & 5 \\
\hline C. lutzi & 21 & 0 & 21 & 1 & 8 & 1 & 0 & 0 & 0 & 0 & 0 & 0 & 1 & 0 & 51 & 2 & 53 \\
\hline C. paraensis & 0 & 0 & 12 & 2 & 2 & 1 & 0 & 0 & 0 & 0 & 0 & 0 & 0 & 0 & 14 & 3 & 17 \\
\hline C. paucienfuscatus & 0 & 0 & 1 & 0 & 1 & 0 & 0 & 0 & 0 & 0 & 0 & 0 & 0 & 0 & 2 & 0 & 2 \\
\hline C. pseudodiabolicus & 348 & 2 & 253 & 11 & 53 & 4 & 0 & 0 & 0 & 0 & 0 & 0 & 0 & 0 & 654 & 17 & 671 \\
\hline C. quasiparaensis & 1 & 0 & 0 & 0 & 0 & 0 & 0 & 0 & 0 & 0 & 0 & 0 & 0 & 0 & 1 & 0 & 1 \\
\hline C. reticulatus & 0 & 0 & 15 & 0 & 2 & 0 & 0 & 0 & 0 & 0 & 0 & 0 & 0 & 0 & 17 & 0 & 17 \\
\hline C. verecundus & 0 & 0 & 1 & 0 & 1 & 0 & 0 & 0 & 0 & 0 & 0 & 0 & 0 & 0 & 2 & 0 & 2 \\
\hline Total & 855 & 43 & 856 & 39 & 198 & 26 & 9 & 0 & 1 & 0 & 3 & 0 & 8 & 8 & 1930 & 116 & 2046 \\
\hline
\end{tabular}

Of the specimens collected in CDC, $898(43,90 \%)$ were captured in the trap settled at $1 \mathrm{~m}$ height from the soil; $895(43,74 \%)$ were collected at $5 \mathrm{~m}$ height and $224(10,95 \%)$ were found in the trap settled at $10 \mathrm{~m}$ height.

In the collections at bases of tree-trunks 16 specimens of four species were captured: C. hylas ( 5 females and 8 males), C. dasyophrus Macfic, 1940 (1 female), C. lahillei Iches, 1906 (1 female) and C. lutzi Costa Lima, 1937 (1 female). Culicoides hylas was the only species who had male specimens, captured in catches on bases of the tree-trunks, with a frequency of $0,63 \%$ of the total, while $C$. dasyophrus, C. lahillei and C. lutzi ocurred together and with a frequency of $0.05 \%$.

From the 13 specimens captured in the Disney traps, nine were captured with Didelphis sp. bait, three with Gallus sp. bait and one with Mesocricetus sp. This kind of strategy collected only C. fusipalpis specimens.

No collections were obtained with the Malaise and Suspended traps.

\section{Vertical stratification}

The results were obtained with the CDC trap.

In the CDC trap settled at $1 \mathrm{~m}$ height we collected 9 species, in the CDC at $5 \mathrm{~m}$ height we captured 14 species and in the one settled at $10 \mathrm{~m}$ height we collected 13 species (Tab. I).

In the CDC trap settled at $1 \mathrm{~m}$ height above the soil we collected 898 specimens of the following species: 380 females of $C$. fusipalpis, 350 (348 females and 2 males) of $C$. pseudodiabolicus, 118 ( 77 females and 41 males) of $C$. hylas, 21 females of $C$. lutzi, 15 females of $C$. foxi, 11 females of $C$. lahillei, 1 female of C. glabrior Macfie, 1940, 1 female of C. insignis Lutz, 1913 and 1 female of $C$. quasiparaensis Clastrier, 1971. 
In collects with CDC traps settled at $5 \mathrm{~m}$ height from the soil 895 specimens were found: 418 (413 females and 5 males) of C. fusipalpis, 264 (253 females and 11 males) of $C$. pseudodiabolicus, 79 ( 66 females and 13 males) of C. hylas, 48 females of $C$. foxi, 25 (19 females and 6 males) of C. lahillei, 22 ( 21 females and 1 male) of C. lutzi, 15 females of C. reticulatus Lutz, 1913, 14 (12 females and 2 males) of $C$. paraensis Goeldi, 1905, 3 females of $C$. dasyophrus, 3 (2 females and 1 male) of C. leopoldoi Ortiz, 1951, 1 female of C. bricenoi Ortiz, 1951, 1 female of C. eublepharus Macfie, 1948, 1 female of C. paucienfuscatus Barbosa, 1947 and 1 female of C. verecundus Macfie, 1948.

In collections with $\mathrm{CDC}$ traps settled at $10 \mathrm{~m}$ height from the soil we collected 224 specimens: 70 (67 females and 3 males) of $C$. fusipalpis, 57 (53 females and 4 males) of $C$. pseudodiabolicus, 42 (26 females and 16 males) of $C$. hylas, 21 females of C. lahillei, 13 females of $C$. foxi, 9 ( 8 females and 1 male) of $C$. lutzi; 3 ( 2 females and 1 male) of $C$. paraensis, 2 ( 1 female and 1 male) of $C$. dasyophrus, 2 females of $C$. leopoldoi, 2 females of $C$. reticulatus, 1 female of $C$. bricenoi, 1 female of $C$. paucienfuscatus and 1 female of $C$. verecundus.

The species C. fusipalpis, C. pseudodiabolicus, C. hylas, C. foxi, C. lahillei and $C$. lutzi were common at three levels. C. quasiparaensis, C. glabrior and $C$. insignis were collected only at $1 \mathrm{~m}$ height. C. paraensis, C. reticulatus, C. leopoldoi, C. dasyophrus, C. bricenoi, C. paucienfuscatus and C. verecundus were common in the CDC at 5 and $10 \mathrm{~m}$; while C. eublepharus was collected only at $5 \mathrm{~m}$ height.

\section{DISCUSSION}

\section{Efficiency of traps and baits}

During the period of February 1990 to January 1991 the collection methods used showed differences as to the efficiency of the capture of Culicoides.

On the bases of the trees-trunks we collected only four species in 16 specimens $C$. hylas (5 females, 8 males), C. dasyophrus (1 female), C. lahillei (1 female) and C. lutzi (1 female) which not only represents a low diversity of species but also proved to be inefficient in the capture of these insects. This methodology in fact, has not been used by others authors for collecting Culicoides.

In the Disney traps with three different baits, $C$. fusipalpis, the only species collected with this strategy showed a preference to the bait Didelphis sp.; CASTELLÓN \& FERREIRA (1991) using animal baits at night collected, four anthropophilous species, demonstrating that $C$. fusipalpis and $C$. foxi were the most frequent species. These facts proved that $C$. fusipalpis has a tendency toward zoophilia and anthropophilia. According to TURNER (1972), the traps with animal bait are very used in studies of the activity of adult of the bloodsucking species of Culicoides. According to HAIR \& TURNER (1968) a great diversity of blood sources is available to female Culicoides and the potential of these insects acting as vectors of a disease depends strongly on its blood sources. JAMBACK \& WATHEWS (1963) and HAIR \& TURNER (1968) reported that $C$. sanguissuga feeds in a great order of hosts such as birds (turkey and chicken) and mammals (goats, rabbits and hamsters). Our results do not 
prove this assertion, since with baits of Gallus sp. and Mesocricetus sp., the results were negative; HUMPREYS \& TURNER (1973) used hamsters as baits, but their use was interrupted after 10 nights of collections, because they captured few Culicoides. According to these authors, if there are factors such as $\mathrm{CO}_{2}$, dampness perspiration, body heat or other not specified emanations from the host it could be considered the hypothesis of that as bigger the quantity of attractives. GUTTMAN (1972) used little animals (rabbits, chickens and hamsters) as baits and concluded that do not attract the main species who attack big animals and the man. TIKASINGH (1972) in collections with human bait collected four species of Culicoides: C. diabolicus, $C$. pusillus, C.furens and C. foxi; CASTELLón (comunicação pessoal); CASTELLón (1990) and CASTELLÓN \& FERREIRA (1991) used the same methodology and showed the anthropophilic behavior of seven species: C. foxi, C. fusipalpis, C. lahillei, C. paraensis, $C$. pseudodiabolicus and $C$. todatangae. According to CASTELLón \& FERREIRA (1991), the diversity of bloodsucking species is connected to the preference for hosts and attractivenes of traps and baits, among others factors.

The Malaise and Suspended traps did not prove to be efficient in collecting of Culicoides, a fact also observed by COSTA (comunicação pessoal).

\section{Vertical stratification}

The specimens of the genus Culicoides appeared more frequently in the CDC traps put at 1 and $5 \mathrm{~m}$ of height from the soil, with strong predominance of three species: C. fusipalpis, C. pseudodiabolicus and C. hylas, followed by C. foxi, yet in the trap put at $10 \mathrm{~m}$ the number of specimens of these species was minor (Tab. I). Other species collected are listed in table I.

The CDC trap with the highest diversity of captured species was that put at $5 \mathrm{~m}$ height (14), followed by the trap at $10 \mathrm{~m}(13)$ and that at $1 \mathrm{~m}(9)$. Six species $(C$. foxi, C. fusipalpis, C. hylas, C. lahillei, C. lutzi and C. pseudodiabolicus) were found at the three levels, however, with different frequencies, and seem to respond in the same way to the climatic and biological conditions reigning in the place. Only three species at the $1 \mathrm{~m}$ level appeared: C. glabrior, C. insignis and C. quasiparaensis. The latter for the number of specimens collected can be considered as a rare species in the place. At the levels of 5 and $10 \mathrm{~m}$ there was a difference relative to the number of captured specimens, but not to the number of species: seven species were common at these two levels: C. bricenoi, C. dasyophrus, C. leopoldoi, C. paraensis, $C$. paucienfuscatus, $C$. reticulatus and $C$. verecundus; probably showed this behavior in function of the search for blood as food and of its phototaxia. KETTLE (1962) mentioned that some species of Culicoides are common at the soil level others are frequent in the canopy of the trees, and some are equally abundant at all heights. WILLIAMS (1955) observed in Georgia that of all collected species of Culicoides $44 \%$ were at $2 \mathrm{~m}$ of height, $15 \%$ at $8 \mathrm{~m}$, and $40 \%$ at $13 \mathrm{~m}$. CASTELLÓN et al. (1993) in collections made with CDC at $4 \mathrm{~m}$, in an area of secondary forest in the Ducke Reserve, reported the presence of 23 species, the most abundant were C. hylas $(52,94 \%)$ and $C$. pseudodiabolicus $(24,10 \%)$ of which the species $C$. foxi and $C$. fusipalpis were captured with lower frequency. CASTELLÓN et al. (1990) worked in three different areas in the brazilian Amazon and found that $C$. pseudodiabolicus 
and $C$. hylas were the most abundant species, however in the present study the frequency at the different heights of these two species was inverted. The collections of $C$. fusipalpis and $C$. foxi were very inexpressive in the different altitudinal layers. These results are evidence that there occurs a substitution of species in different areas and that the major or minor abundance of species could depend on the different traps and baits used, period of collects and altitudinals layers, not excluding the weather factors among others. According to CHANIOTIS et al. (1971), "The seasonal dynamics of the phlebotomines population are the product of a complex interplay between the biotic potential of different species and the resistance of the environment the eatter of a number of abiotic physical variables".

ACKNOWLEDGEMENTS. To Drs Christopher Martius and Mariana Oliveira Dos Santos for helping in the translations and Jose Souza Lira by typing the manuscript.

\section{REFERENCES}

AUBRÉVILLE. 1961. Étude écologique des principales formations végétales du Brésil et contribution a la connaissance des forêts de La Amazonie Brasilienne. France, Centre Technique Forestier Tropical, Nogent Sur-Marne, II $+268 \mathrm{p}$.

Castellón, E.G. 1990. Culicoides (Diptera: Ceratopogonidae) na Amazônia brasileira. II. Espécies coletadas na Reserva Florestal Ducke, aspectos ecológicos e distribuição geográfica. Acta Amazonica 20: 83-93.

CAstellón, E.G. \& R.L.M. FerReIRA. 1991. Culicoides Latreille (Diptera:Ceratopogonidae)da Amazônia. III. Resultados de coletas noturnas, na Reserva Florestal Ducke, Estado do Amazonas, Brasil. Bol. Mus. Pará Emilio Goeldi, sér. Zool., 7 (2): 117-123.

Castellón, E.G; R.L.M. Ferreira \& M.N.T. Silva. 1990. Culicoides (Diptera: Ceratopogonidae) na Amazônia brasileira. I. Espécies coletadas na Usina Hidrelétrica (UHE) de Balbina, Usina Hidrelétrica (UHE) Cachoeira Porteira e Cachoeira dos Espelhos (Rio Xingú). Acta Amazonica 20: 77-81.

. 1993. Culicoides (Diptera: Ceratopogonidae). In the brazilian Amazon. IV. Species collected with CDC light trap in the Ducke Forest Reserve (RFD), Amazon State, Brazil. Acta Amazonica 23 (2-3): 309-310.

ChANIOTIS, B.N.; J.M. NEELY; M.A. CORREA; R.B. TESH \& K.M. JONHSON. 1971. Natural population dynamics of phlebotomine sandflies in Panama. Jour. Med. Ent. 8 (4): 339-352.

DISNEY, R.H. 1965. A trap for Phlebotomine sandflies attracted to rato. Bull. Ent. Res. 56: 445-51.

Forattini, O.P.; E.X. Rebello \& D. PATtoli. 1958. Culicoides da região Neotropical (Diptera: Ceratopogonidae). I. Observações sobre a biologia em condições naturais. Arqvs Fac. Hig. Saúde Públ. Univ. São Paulo 12 (11): 1-52.

GuTTMAN, D. 1972. The biting activity of black flies (Diptera: Simuliidae) in three types of habitats in Western Colombia. Jour. Med. Ent. 9 (5): 296-276. 
HAIR, J.A. \& E.C. TURNER JR. 1968. Preliminary host preference studies on Virginia

Culicoides (Diptera: Ceratopogonidae). Mosquito News 28 (1): 103-107.

HigUCHI, N. 1981. A silvicultura no INPA. Acta Amazonica 11 (1): 99-107.

HUMPHREYS \& E.C. TURNER JR.. 1973. Blood-feeding activity of female Culicoides

(Diptera: Ceratopogonidae). Jour. Med. Ent. 10 (1): 79-83.

JAMBACK, H. \& T. WATTHEWS. 1963. Studies of populations of adult and immature

Culicoides sanguisuga (Diptera: Ceratopogonidae). Ann. Entomol. Soc. Amer. 56: 728-732.

KettLe, D.S. 1962. The bionomics and control of Culicoides and Leptoconops (Diptera: Ceratopogonidae: Heleidae). Ann. Rev. Ent. 7: 401-418.

LECHTHALER, R. 1956. Inventário das árvores de um hectare de terra firme da zona "Reserva Florestal Ducke" Município de Manaus. INPA, Série Botânica (3): $1-7$.

Rafael, J.A. \& I.S. Gorayeb. 1982. Tabanidae (Diptera) da Amazônia. I. Uma nova armadilha suspensa e primeiros registros de mutucas de copa de árvores. Acta Amazonica 12 (1): 232-236.

SHERLOCK, I.A. \& N. GUITTON. 1964. Dermatozonosis by Culicoides bite (Diptera: Ceratopogonidae) in Salvador, state of Bahia, Brasil. I. Entomological survey. Mem. Inst. Oswaldo Cruz 62: 53-62.

Sudia, W.D. \& R.W. Chamberlain. 1962. Battery - operated light trap, an improved model. Mosquito News 22: 126-129.

TIKASINGH, E.S. 1972. Seasonal and diurnal activities of four species of trinidadian Culicoides (Diptera: Ceratopogonidae). Mosquito News 32 (3): 447-452.

Townes, H. 1962. Design for a malaise trap. Proc. Ent. Soc. Wash. 64 (4): 253-262.

TURNER JR., E.C. 1972. An animal-baited trap for the collection of Culicoides spp. (Diptera: Ceratopogonidae). Mosquito News 32 (4): 527-530.

Williams, R.W. 1955. Studies on the Culicoides of Baker Country, Georgia (Diptera: Heleidae). Ann. Ent. Soc. Amer. 48 (1-2): 29-34.

Recebido em 28.II.1997; aceito em 13.IV.1998. 